\title{
Photoreceptors, Invertebrate
}

National Cancer Institute

\section{Source}

National Cancer Institute. Photoreceptors, Invertebrate. NCI Thesaurus. Code C12635.

Specialized cells in invertebrate animals that convert light signals into nerve impulses. 